\title{
Does simplified accounting limit small and micro companies' access to bank financing?
}

\author{
Halina Waniak-Michalak ${ }^{\mathrm{a}, 1}$ \\ ${ }^{a}$ University of Lodz, Poland
}

\begin{abstract}
Enterprises that use simplified accounting can provide less information to lenders, thereby possibly hampering risk analysis. In this paper I investigate whether simplified accounting is a barrier for Polish Small and Medium-sized Entities (SMEs) enterprises to access financing resources, or makes funding more expensive for them. Telephone interviews with managers of banks and a review of statistical data are used to show that simplified accounting methods may influence the cost of capital of Polish SMEs, but it does not create a barrier to accessing external sources of financing.
\end{abstract}

Keywords: SME; micro entities; bank financing; simplified accounting; Poland

\section{JEL codes: M21, M41}

\section{Introduction}

The problem of difficult access for small and micro enterprises to external capital, especially to commercial sources of funding, is presented in many publications (Nassr \& Wehinger, 2015, Duan; Han \& Yang, 2009; Biernat \& Planutis, 2013; Cassar, 2004; Udell, 2015). This is a barrier for development that stems from the low credit rating and high credit risk attributed to small companies. There are several major reasons for which these businesses may be perceived as riskier: lack of sufficient collateral (Czajkowska, 2013), the legal status (partnerships or proprietorships) (Bauer, 2013), inadequate knowledge of financial management (i.e.

${ }^{1}$ Corresponding author: University of Lodz, Management Department; Matejki St. 22/26, 90-237; tel. (+48) 4263552 34; e-mail address: hwaniak@uni.lodz.pl 
the inability to estimate the cost of capital, to assess the profitability of investments, to manage the risk) (European Parliament, 2012) and scope of accounting (Ayadi \& Gadi, 2013). Small companies may be perceived as even riskier in developing countries, such as Poland, where the economy is less stable than in mature markets (Beck et al., 2008). This is why in these countries banks are less interested in investing in small companies than in developed countries (Dalberg, 2011).

Accounting has many ways of application. It is used by business entities, but also by non-profit organizations, professionals and governmental institutions. The principle role of accounting is to provide an information useful for users (managers, owners). The dimension of accounting (the scope of accounting) can be very narrow and ends with recording economic transactions or preparing financial statements. However, in a modern world, an accounting may also serve to "identify, measure and communicate economic information to permit informed judgments and decisions by the users of accounts" (Porter \& Norton, 2014), so the scope of accounting may be much broader.

The scope of accounting and reporting is closely related to the legal status of a business registered in Poland. In capital companies (not using simplified accounting), in which the concept of separate entity is used, the assessment of credit risk is easier and less costly than in the case of the self-employed or microcompanies. Moreover, ownership structure determines the level of tolerable financial risk. Family businesses operating mainly to provide an income for the owner and the members of his/her family reluctantly become indebted due to the fact that this is a threat to the stability of family life (Starczewska-Krzysztoszek, 2014). Thus, in this paper I investigate whether simplified accounting is a barrier for Polish Small and Medium-sized Entities (SMEs) enterprises to access financing resources, or makes funding more expensive for them.

The first part of the paper describes accounting regulations for small and micro enterprises in Poland and what kind of simplifications in accounting Polish businesses may use. The second section presents the literature review on the influence of simplified accounting on an access of small companies to finance. The last part of the paper shows results of interviews with bank managers and findings on the bank's offer for small businesses.

The findings may be important for all researchers interested in the role of financial information in the decision making of creditors and the consequences of the simplification of accounting for access of small companies to bank finance (including IFRS for SMEs). In order to reach our goal, literature research and interviews with five banks managers were used. Interviews with bank managers were anonymous, because official permission of the bank headquarters for the interview is almost not possible to obtain in Poland. Access to more managers was extremely challenging despite numerous attempts. While this impairs generalizability of 
findings via such a small number of interviews, this data nicely complements statistical data and our in-depth understanding of the polish case.

\section{Accounting Regulations for Small and Micro Enterprises in Poland}

Small and micro enterprises, depending on the type of business and its size, fall under different accounting and tax regulations. The basic legal act regulating the activity of business units receiving income more than 1,200,000 EUR is the Accounting Act issued on the 29 of September 1994 (with further refinements).

On September 5 2014, the regulator introduced a new category of business entity, the micro and small unit, which do not have to use all the regulations of the Accounting Act. It was forced by the UE Directive 2013/34/EU of the European Parliament and of the Council of 26 June 2013 on the annual financial statements, consolidated financial statements and related reports of certain types of undertakings. Limits of revenues, balance sheet sum for micro, small and mediumsize entities indicated in the Directive were presented in the Polish Accounting Act in PLN. Therefore, the regulator included in this group of micro entities firms that do not exceed two of the three following amounts:

a) 1,500,000 PLN - balance sheet sum,

b) 3,000,000 PLN - annual revenue,

c) 10 employees - average annual number of full time employees (FTE)

These micro-entities can prepare simplified financial statements, including a balance sheet and a profit and loss statement.

Small entities, according to the Polish Accounting Act, are firms that do not exceed two of the following three amounts:

a) 17,000,000 PLN - balance sheet sum,

b) 34,000,000 PLN - annual revenue,

c) 50 employees - average annual number of full time employees (FTE)

Small entities additionally have the right to prepare simplified financial statements, however they are more detailed than the statements of micro enterprises. Entities that do not reach revenues of 1200000 EUR have to follow the regulations of the Income Tax Act for individuals, according to which, particular entities are required to keep a revenue and expense ledger and others will pay the flat rate of tax on registered income or pay a fixed tax using a tax card (Table 1). 
Does simplified accounting limit small and micro companies' access to bank financing?

Table 1. The scope of bookkeeping and reporting of Polish business units in connection with the chosen form of taxation and size of activity

\begin{tabular}{|c|c|c|c|}
\hline $\begin{array}{c}\text { Type of } \\
\text { accounting }\end{array}$ & Conditions & Description & $\begin{array}{c}\text { Information } \\
\text { provided }\end{array}$ \\
\hline Tax card & $\begin{array}{ll}\text { - } & \text { revenues }<150,000 \\
\text { Euro } \\
\text { - Activity described in } \\
\text { article } 3 \text { of the Income } \\
\text { Tax Act } \\
\text { - number of employees }< \\
3\end{array}$ & $\begin{array}{l}\text { tax is paid as a } \\
\text { lump sum, } \\
\text { regardless of the } \\
\text { value of revenues } \\
\text { and costs incurred }\end{array}$ & $\begin{array}{l}\text { - } \\
\text { - } \quad \text { copy of invoices register } \\
\text { of sale and } \\
\text { purchase }\end{array}$ \\
\hline $\begin{array}{l}\text { Tax on registered } \\
\text { income: }\end{array}$ & $\begin{array}{l}\text { - } \quad \text { revenues }<150,000 \\
\text { Euro } \\
\text { - } \quad \text { activity described in } \\
\text { art. } 2 \text { and } 8 \text { of the } \\
\text { Income Tax Act } \\
\text { number of employees } \\
>3\end{array}$ & $\begin{array}{l}\text { tax is paid as a } \\
\text { percentage of the } \\
\text { registered revenues } \\
\text { (costs are not taken } \\
\text { into account) }\end{array}$ & $\begin{array}{ll}\text { - } & \text { salaries register } \\
\text { - } & \text { copy of invoices } \\
\text { of sale and } \\
\text { purchase } \\
\text { - } & \text { register of } \\
\text { equipment and } \\
\text { intangible assets } \\
\text { - } \begin{array}{l}\text { register of } \\
\text { supplies }\end{array}\end{array}$ \\
\hline $\begin{array}{l}\text { Revenue and } \\
\text { expense ledger }\end{array}$ & $\begin{array}{l}\text { - } \text { revenues }<1,200,000 \\
\text { Euro } \\
\text { - } \text { partnership or } \\
\text { proprietorship }\end{array}$ & $\begin{array}{l}\text { The company pays } \\
\text { the tax depending } \\
\text { on its income } \\
\text { (revenues minus } \\
\text { costs). The } \\
\text { company uses tax } \\
\text { regulation instead } \\
\text { of the Accounting } \\
\text { Act to record } \\
\text { revenues and costs, }\end{array}$ & $\begin{array}{ll}\text { - } & \text { revenue and } \\
\text { expense, financial } \\
\text { results } \\
\text { - } & \text { register of salaries } \\
\text { - } & \text { register of } \\
\text { equipment and } \\
\text { intangible assets } \\
\text { plus amortization } \\
\text { plan } \\
\text { - record of the } \\
\text { vehicle usage and } \\
\text { supplies }\end{array}$ \\
\hline $\begin{array}{l}\text { Full Accounting for } \\
\text { micro companies }\end{array}$ & $\begin{array}{l}\text { Fulfilment of } 2 \text { of the } \\
\text { following } 3 \text { requirements: } \\
\text { 1. balance sheet sum < } \\
1,500,000 \text { PLN, } \\
\text { 2. net sales }<3,000,000 \\
\text { PLN, } \\
\text { 3. average employment } \\
\text { <10 FTE } \\
\text { - legal status of capital } \\
\text { company }\end{array}$ & $\begin{array}{l}\text { Full accounting } \\
\text { with some } \\
\text { exceptions, such } \\
\text { as: simplified } \\
\text { financial } \\
\text { statements, } \\
\text { possibility to use } \\
\text { tax regulations in } \\
\text { place of accounting } \\
\text { regulations. Notes } \\
\text { for financial } \\
\text { statements are not } \\
\text { necessary }\end{array}$ & $\begin{array}{l}\text { Information from } \\
\text { the accounting } \\
\text { system: costs, } \\
\text { revenue, assets } \\
\text { and liabilities, } \\
\text { A simplified } \\
\text { financial } \\
\text { statement for } \\
\text { micro entities } \\
\text { including: } \\
\text { revenue from sale } \\
\text { and other revenue } \\
\text { (without details), } \\
\text { main positions of } \\
\text { assets and } \\
\text { liabilities. }\end{array}$ \\
\hline
\end{tabular}




\begin{tabular}{|c|c|c|c|}
\hline $\begin{array}{c}\text { Type of } \\
\text { accounting }\end{array}$ & Conditions & Description & $\begin{array}{c}\text { Information } \\
\text { provided }\end{array}$ \\
\hline $\begin{array}{l}\text { Full Accounting for } \\
\text { small companies }\end{array}$ & $\begin{array}{l}\text { Fulfilment of } 2 \text { of the } \\
\text { following } 3 \text { requirements: } \\
\text { - balance sheet sum < } \\
17,000,000 \text { PLN, } \\
\text { - net sales }<34,000,000 \\
\text { PLN, } \\
\text { average employment }<50 \\
\text { FTE }\end{array}$ & $\begin{array}{l}\text { Simplified } \\
\text { financial } \\
\text { statements, without } \\
\text { a statement of the } \\
\text { changes in equity } \\
\text { or a cash flow } \\
\text { statement as well } \\
\text { as activity } \\
\text { statement on the } \\
\text { condition that the } \\
\text { information will be } \\
\text { presented in notes } \\
\text { for the financial } \\
\text { statement. In } \\
\text { addition, financial } \\
\text { ratios and } \\
\text { information on the } \\
\text { influence of the } \\
\text { entity on the } \\
\text { environment are } \\
\text { not required. }\end{array}$ & $\begin{array}{l}\text { Information from } \\
\text { the accounting } \\
\text { system: costs, } \\
\text { revenue, assets } \\
\text { and liabilities, } \\
\text { financial } \\
\text { statement for } \\
\text { small entities }\end{array}$ \\
\hline
\end{tabular}

Source: Own elaboration on the basis: Dz.U. z 1998 r. n. 144.; Dz.U. 1991 n. 80; Dz.U. 1988 n. 44; Dz.U. 1994 n. 121.

It must be noted that every business entity in Poland may choose not to use simplified accounting, even those that record revenues lower than 150,000 EUR. However, despite such a possibility, many small businesses use simplified accounting, recording only revenue (revenue card for each employee in the case of the tax card) and wages. Research shows that only $16.79 \%$ of SMEs and $6 \%$ of micro-enterprises kept full accounting (Fundacja Rozwoju Biznesu [Foundation for Business Development], 2013), while most (approx. 70\% of enterprises) use a revenue and expense ledger (see Figures $1 ; 2 ; 3$ ). Only about $6-7 \%$ of micro enterprises use full accounting and $65 \%$ of small companies, implying that the problem with access to external financing may affect only $1 / 3$ of small companies but more than $90 \%$ of micro enterprises. If we exclude the revenue and expense ledger, the biggest problem concerns only micro enterprises (Figure 2 and 3 ), because almost only micro entities use tax on registered income and revenue and expense ledger. 
Does simplified accounting limit small and micro companies' access to bank financing?

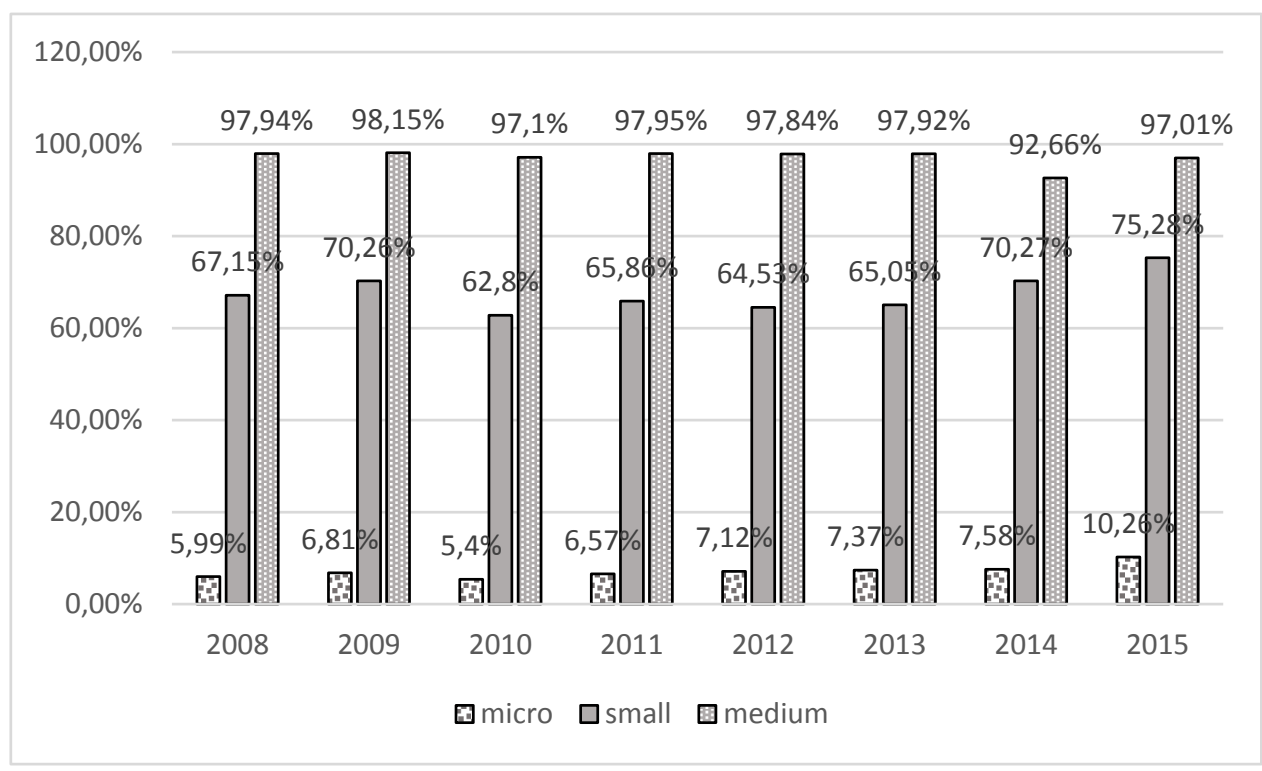

Figure 1. Share of number of enterprises not using simplified accounting in the number of SMEs in Poland in the years 2008-2015

Source: Own elaboration on the basis of statistical data of the General Statistics Office: „Działalność przedsiębiorstw niefinansowych” [Activity of nonfinancial enterprises] for the years 2008, 2009, 2010, 2011, 2012, 2013, 2014, 2015

The revenue and expense ledger must be kept by entrepreneurs in Poland who receive annual income higher than 150,000 EUR., that is, those who cannot pay income tax on the basis of a flat rate of recorded income or the tax card. The income and expense ledger is a form of taxation and bookkeeping (most popular among micro-entities and second most popular among small businesses) (Figure 2). It must be noted that the least popular forms of accounting are flat rate tax and the tax card, i.e. the simplest tax and accounting forms (Figure 3). However, they also cause the highest difficulties in obtaining external financing (Pogodzińska-Mizdrak, 2008) and the inability to subtract operating expenses from revenue (including reporting losses during economic crises and the possibility to pay lower tax in the following years). Despite the constraints of the information contained in the revenue and expense ledger, it is a reliable source of information for lenders. In comparison with other simplified forms of bookkeeping, it does not create a large obstacle in obtaining external financing. It is possible to conduct a financial analysis of the entity and even prepare financial statements to apply for external financing (i.e. EU grants) (Jaworski, 2009) by taking into account such data from the revenue and expense ledger as:

1) sales revenues,

2) other revenues, 
3) values of purchases,

4) additional costs of purchases,

5) wages and salaries, in cash and in kind,

6) other expenses,

7) register of plant, property and equipment and intangibles,

8) register of cash, receivables and payables (not obligatory, but some enterprises keep records),

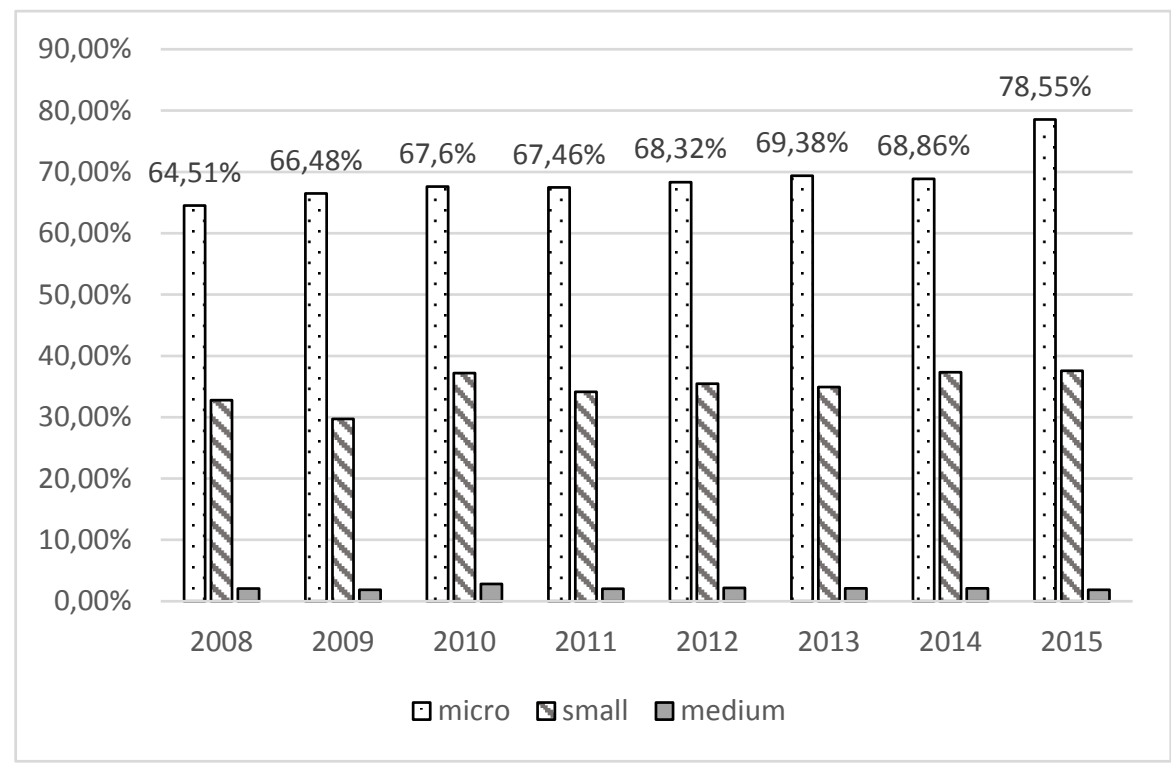

Figure 2. Share of number of enterprises using the revenue and expense ledger in the number of SMEs in Poland in the years 2008-2015

Source: Own elaboration on the basis of statistical data of the General Statistics Office: „Działalność przedsiębiorstw niefinansowych” [Activity of nonfinancial enterprises] for the years 2008, 2009, 2010, 2011, 2012, 2013, 2014, 2015

Simplified taxation and accounting forms are used in many countries as an incentive for entrepreneurs to set up a business in the form of a proprietorship or partnership (often a family business) (Żabiński, 2011). Simplified forms of taxation and accounting such as a flat rate of recorded income or a tax card are designed for microcompanies operating to a limited extent, so these forms of taxation do not occur in the group of small and medium-sized enterprises.

The use of these forms of taxation and accounting enables a considerable simplification of bookkeeping, documentation, and a decrease of the cost of control on the side of the tax authorities. The amount of tax to be paid by the entrepreneur 
keeping the tax card depends on the type of services provided and the size of the premises where the activity is run.

On the other hand, these forms of accounting limit the selection of: the type of activity (some forms of bookkeeping like the tax card or tax on registered income are available for just a few types of activity), the number of employees (up to 5 people for a tax card), the amount of revenue or income, and thus the number of services or products sold (i.e. number of lessons given by tutors). A flat rate of recorded income can be used by Polish entrepreneurs if their revenue for the previous year did not exceed 150,000 EUR. This possibility to select the form of accounting and taxation is also limited by the type of business, for example, entrepreneurs serving financial services or freelancers cannot use the flat rate of recorded income.

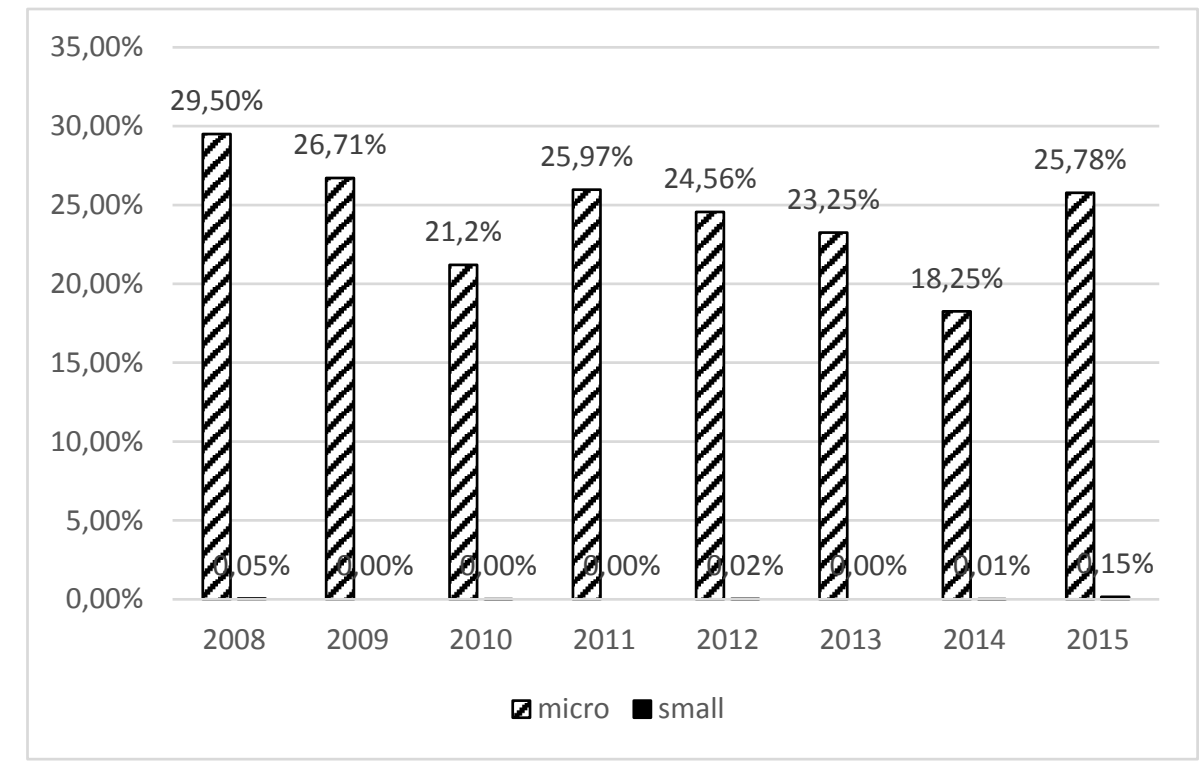

Figure 3. Share of number of enterprises using the flat rate of recorded income or the tax card in the number of SMEs in Poland in the years 20082015

Source: Own elaboration on the basis of statistical data of the General Statistics Office: „Działalność przedsiębiorstw niefinansowych” [Activity of nonfinancial enterprises] for the years 2008, 2009, 2010, 2011, 2012, 2013, 2014, 2015.

According to GUS (General Office of Statistics) data for the years 2010-2015, the scope of accounting (full accounting, revenue and expense ledger, tax on registered income or the tax card) affects the amount of investments. It is difficult to say whether this is due to the lower capital requirements or difficulties in obtaining funds for projects. 


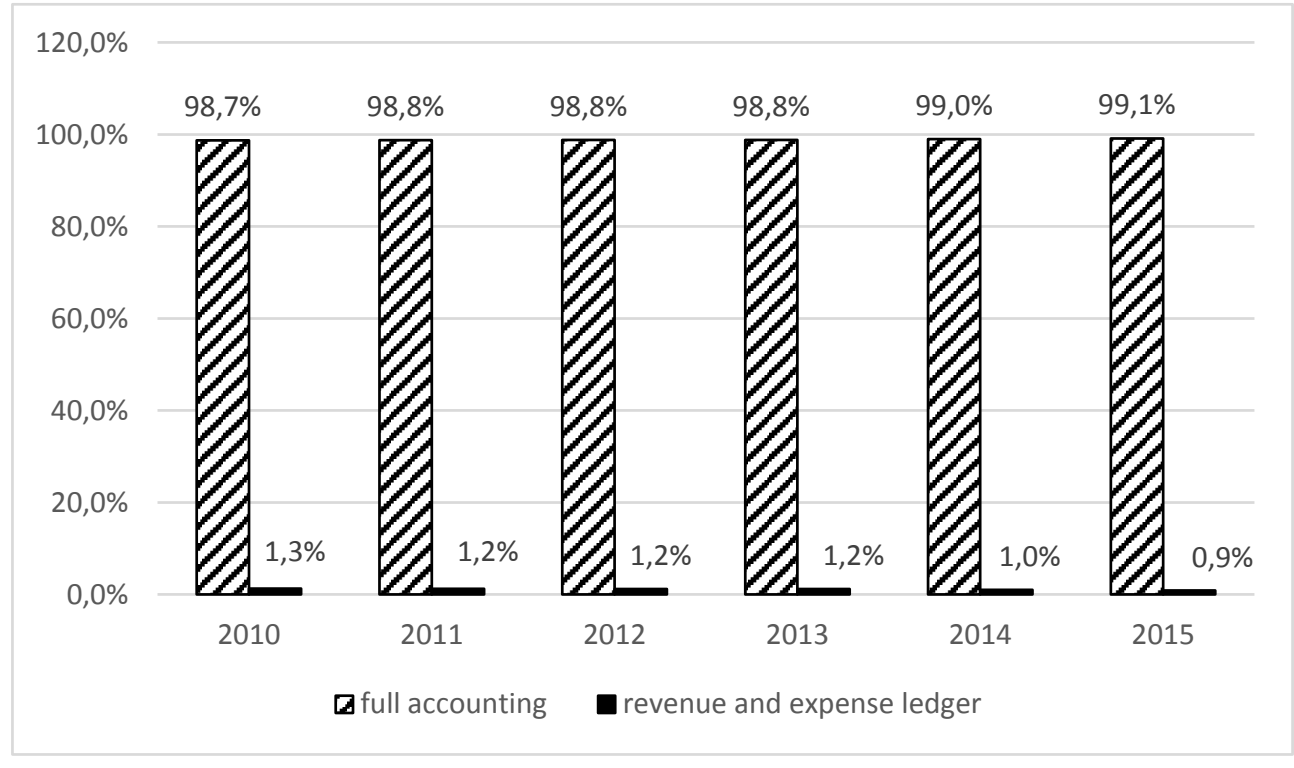

Figure 4. Share of value of investments of companies with more than 10 employees: using full accounting or revenue and expense ledger

Source: Own elaboration on the basis of statistical data of the General Statistics Office: , Bilansowe wyniki finansowe podmiotów gospodarczych w 2015" [Balance sheet financial results of business entities in 2015]

Figure 4 shows that the value of investments in property, plant and equipment of enterprises using the revenue and expense ledger hovers around $1 \%$ of all investments in property, plant and equipment of companies. Most enterprises using the revenue and expense ledger work in the following sectors: "manufacturing" (29\%), "trade" (20\%) and "construction" (16\%).

Lower investments may also be related to the legal status of the business unit. Entities keeping simplified accounting, and recording revenues only for tax purposes operate as partnerships or as proprietorships, therefore, they also have personal responsibility for the entities' obligations. The risk from the outstanding debt and any investment projects is perceived differently and limited to a greater extent than in capital companies (Bauer, 2013).

Costs related to the scope of accounting depend on the location of the business, its type and its size. The following table presents a comparison of the costs of bookkeeping and the tax burden. 
Does simplified accounting limit small and micro companies' access to bank financing?

\begin{tabular}{lcr}
\hline Table 2. Comparison of the cost of bookkeeping and the tax burden \\
for different forms of accounting in Poland \\
for
\end{tabular}

Source: Own elaboration on the research of the proposals of 20 accounting offices in Poland, and the Income Tax Act Dz.U. $1991 \mathrm{nr} 80$ poz. 350,

\section{Impact of Simplified Forms of Accounting on Access to External Financing}

In many countries, simplified, cash-based forms of accounting are allowed (Bergner \& Heckemeyer, 2016). Certain studies have argued that small businesses consider the option to choose simplified tax accounting in their choice of legal status. Simplified forms of accounting (bookkeeping) are provided in many countries to make the calculation of tax easier for entrepreneurs (Czaja-Cieszyn, 2009). However, the problem of access to external financing was not a major concern for the regulators, as small enterprises finance their projects mainly through their own sources, thus demand for external financing is low (Mikócziová, 2010). The growth of a business would lead to the need to opt for the revenue and expense ledger or full accounting, especially when the legal status of the business changes. Nevertheless, even in this situation, business entities may choose to prepare simplified financial statements.

In Poland, additional simplifications for micro and small businesses were introduced in 2015 and 2016 in response to EU Directive 2013/34 (Klimczak \& Krasodomska, 2017). At present, small capital companies may use a simplified method for the valuation of assets and liabilities and prepare simplified financial statements. Research shows that the introduction of these simplifications may result in savings in the region of 17 million PLN for companies using these facilitations (Mścibrodzka, 2014).

However, financial statements, also simplified, are aimed at providing useful information to users of the information. For many years, the discussion has been ongoing over whether increasing the information in financial statements contributes 
to the increase of their usefulness, and whether it is in line with the expectations of stakeholders (Buk, 2010; Nowak, 2015; Volkov \& Laing, 2012).

Entrepreneurs who use simplified accounting but recognize the shortcomings of the information from their accounting system, voluntarily keep additional accounts, such as receivables and payables accounts (Brest, 2013). They do this because they consider this information crucial either to manage the business or as important for lenders. The business entity when choosing a form of accounting may take into account not only the law, but also the specifics of its activity, the requirements of suppliers and creditors.

Simplifications of accounting for small businesses are however to reduce the cost of accounting and adjust the level of information in financial statements to the scope of activities. Many complicated transactions never occur in the activities of small entities, so certain regulations (like fair value measurement) are not useful. Jóźwicka and Zakrzewska-Bielawska (2014) indicate that particular entrepreneurs, despite being aware of the benefits of keeping full accounting, decide on simplified accounting due to the lack of skilled workers or accounting knowledge of the owner, as well as the cost of software and salary of the accountant.

At this point one question arises, whether such a simplified report will still be useful, and to what extent these simplifications can apply? The exemption of micro entities from preparing additional information means that other parts of their financial statements may not be of value (Maszczak, 2015; Martyniuk, 2016). Moreover, simplified accounting cannot generate enough information for managers, i.e. the costs necessary to make effective management decisions (Szczypa, 2016). Takats (2013) is in disagreement with this assertion, arguing that there is no evidence that along with the simplification of reporting comes the simplification of the information in the accounting system.

As research shows, capital providers criticize simplified accounting not only because of the limited usefulness of information, but also the poor reliability of the data presented in the reports (Jaworski, 2009). Studies reveal that companies that prepare simplified financial statements, also use simplifications that are not allowed in the Accounting Act (Kaczmarczyk, 2014). For example, small businesses use tax regulations for calculation of depreciation, or do not recognize allowances in receivables or other assets. Simply put, small companies often use tax regulations in place of general accounting regulations, because they think that simplification of accounting means that they may use the same regulations for calculation a tax income and a financial result in the income statement (Kaczmarczyk, 2014).

Most owners of micro enterprises indicate that their reasoning behind not using bank loans are the high collaterals required, high funding costs and complicated 
procedures (Banasik \& Napora-Lędźwa, 2014). One of many reasons for the worse credit conditions of small entities is the low quality of financial information provided (Palazuelos et al., 2017; Berger \& Udell, 1995). Sometimes, even preparation of financial statements is not enough to decrease the level of risk, and audited financial statements are required (Berger and Frame, 2007). Some researchers that small companies can have more difficult access to bank loans than larger firms (Schiffer \& Weder, 2001) due to the company's lack of transparency on creditworthiness (Ayadi \& Gadi, 2013). It may be caused by insufficient information on the financial situation of small enterprises. Small and micro enterprises usually can't present financial statements on their revenues, profits and liabilities which may create a significant obstacle for an evaluation of creditworthiness (Dalberg, 2011).

Studies show that small enterprise are attractive but also very risky clients for banks (Kulczycki, 2016). Simplified tax forms like the tax card do not generate any information for stakeholders (including lenders). Thus, the low value of information is often a barrier when applying for external funding. This is because a reliable assessment of the financial situation of the company becomes impossible if there is no data on assets, liabilities and expenses (Fedak \& Osikowicz, 2009). Simplification of the information generated in the accounting system of micro businesses makes the assessment of the financial situation of these entities more difficult than companies keeping full accounting. Difficulties concerning the assessment of the level of financing risk for a company entering the market are large, and lead to the automatic assignment to this type of businesses of the lowest rating, and thus higher interest on loans. Because analysts cannot conduct ratio analysis for companies that do not prepare financial statements, an assessment of credit risk for these entities must be supplemented by qualitative assessment, including an analysis of the market (sales opportunities, competition, product quality, cooperation with suppliers, customers) as well as their history of business and management skills. As research shows, selfassessment by entrepreneurs is much higher than the assessment done by credit institutions. This may explain the reasons why entrepreneurs are dissatisfied with the credit decision given, and search for other reasons for which the loan application was rejected (Sobolewski, 2013).

Keeping simplified accounting may, however, be an obstacle to the development of the company when it becomes necessary to access other sources of financing, such as venture capital funds or EU grants. Applications for funding under the national and regional programs of development in Poland, co-financed with sources from the $\mathrm{EU}$, also require data from the balance sheet, the income statement and the cash flow statement. These reports can be prepared in a simplified form for the two previous financial years and for the current period. A forecast is prepared for the duration of the project and the subsequent three years (for SMEs) after the completion of the project. The content of the application for the grant is uniform for all applicants (though it may vary slightly depending on the program) regardless of their organizational and legal form or scope of accounting. Enterprises that keep the 
revenue and expense ledger or pay tax on registered income or a tax card must also prepare financial statements for previous years and a forecast for the forthcoming few years. In such a situation, it is necessary to enlist the help of consulting firms or accounting offices to prepare the financial information, as inexperienced entrepreneurs are unable to do this without the support of specialists.

In addition, for micro companies or individuals using the tax card or the flat rate on registered income, the problem is to determine the value of fixed assets and inventory, as the personal assets of the owner of the business are often used in their business activity. This problem has been repeatedly considered from the point of view of SMEs' access to grants from international aid programs. However, the benefits of keeping full accounting are not truly recognized by SMEs.

\section{Required Financial Information - Interview and Market Analysis Results}

Entrepreneurs using simplified accounting may have greater difficulty in obtaining the necessary external financing as the limited information from the accounting system does not enable a full risk assessment of the entity's financial situation. Referring to the reporting simplifications for micro entities introduced to the Polish Accounting Act, we can state that these simplifications may, on the one hand, reduce the cost of accounting for small and micro enterprises, but, on the other, these simplifications can deepen the difficulties of SMEs in obtaining capital. As a result, the investments of small and micro enterprises are financed through their own resources, or deferred in time. This causes a mismatch between the needs of entrepreneurs and their financial capacity, and thus is the reason for the lack of growth possibilities and fulfilment of the market demand in a period of economic growth (Bauer, 2013).

Commercial banks take the decision to issue a loan after the analysis of the creditworthiness of the enterprise, i.e. after the evaluation of their financial situation, the ability to repay the debt and the assessment of any existing potential collaterals. The amount of the loan and its cost depend on the result of this analysis; the amount does not always cover all the expected expenses of the investment project's implementation for which the loan is taken. The entrepreneur who keeps a revenue and expense ledger or pays tax in the form of the tax card (one that is not able to provide reliable financial information about his business) stands the least possibility of obtaining a loan.

The analysis of the information presented on the websites of banks (required documents to apply for the loan) did not provide an answer to the question of whether the revenue and expense ledger or other simplified forms of taxation and accounting make access to bank loans more difficult. Depending on the type of credit offered by 
the bank, different financial information or documents may be needed. In most cases, banks require access to the revenue and expense ledger. Entrepreneurs paying a flat rate on registered revenue or the tax card must provide the tax documents submitted to the tax office. However, depending on the financial situation of the entrepreneur, on the amount of the loan requested or on other reasons, the bank may require additional documentation to assess the creditworthiness of the applicant.

In order to answer our research question, direct interviews with managers from five selected banks in Poland were used along with an analysis of the documentation required by banks for loan application ${ }^{\mathrm{ii}}$. Different research methods, like survey or statistical analysis of financial information of SMEs couldn't be used because of lack of financial data on SMEs activity in Poland and high costs of the survey iii.

Interviews were conducted ${ }^{\text {iv }}$ in December 2015 with five employees of different banks in Poland. One of the respondents was a director of the regional division of a bank, and the 4 others were bank consultants. The aim of the study was to answer the question of whether keeping simplified accounting effects an increase in the cost of credit. Three questions were asked:

1. Is it possible to obtain a loan for the company using simplified accounting? If so, what are the requirements?

2. Is that loan more expensive or collaterals higher than for companies using full accounting?

3. Are there any limitations on the amount or purpose of the loan?

Respondents stated that the interest rate on the loan depended on many factors considered in the process of multi-criteria credit rating, such as: character, ability, means (own resources invested in the project), purpose (if the goal is economically justified), amount in comparison with value of assets, suggested methods of repayment and collaterals. However, since the analysis of the creditworthiness of small companies keeping simplified accounting may not be as clear as for other entities (the lack of possibility to calculate financial ratios), the bank's risk is greater for loans to small businesses, thus the loan for these businesses must be more expensive. The threshold of a loan depends on business earnings or the owner's income. Enterprises using a tax card or revenue and expense ledger are treated as individuals when the process of creditworthiness assessment is applied. For example, the value of a loan depends on the value of existing loans of the business owner, their spouse and the income per member of the family. A director of a bank answered that, in his opinion, the key reason for the difficult access of small entrepreneurs to bank loans was the inaccurate estimation of capital needs:

"The owner of a small business is afraid that an application for a higher loan will be rejected, so asks for a lower amount. Then he secures the loan using his machines or other assets. In many cases, the amount of the loan is not sufficient, therefore he must search for a second loan. But it then turns out that he has no more collateral and his application for a loan is rejected. This is not a result of the fact that he runs a small or 
micro company, or that he uses simplified accounting, but a result of his inability to plan his investments over the long term".

Analysis of the market offer revealed that there are two main groups of business clients of banks: small business and companies. However, entrepreneurs running a business in the form of proprietorships are considered to be individuals, therefore their credit conditions are the same as for other non-business clients. Banks accept any financial documents that companies can deliver: financial statements for companies keeping accounting books, copies of revenue and expense ledger or tax reports. Bank charges are similar for corporations and small enterprises, however, possible differences in credit conditions may appear when signing the contract, and concern the total cost of the loan, the period for which the loan is granted and its amount (Table 3).

Table 3. Costs of external financing for companies in Poland

\begin{tabular}{lccccc}
\hline & $\begin{array}{c}\text { Provision } \\
\text { for } \\
\text { operation } \\
\text { loan }\end{array}$ & $\begin{array}{c}\text { Provision for } \\
\text { investment } \\
\text { loan }\end{array}$ & $\begin{array}{c}\text { Credit } \\
\text { administration }\end{array}$ & $\begin{array}{c}\text { Average interest } \\
\text { rate }\end{array}$ & $\begin{array}{c}\text { Preparation } \\
\text { of financial } \\
\text { statements } \\
\text { for grant } \\
\text { purposes }\end{array}$ \\
\hline Small business & $\begin{array}{c}0-7 \% \text { (on } \\
\text { average }\end{array}$ & $1.5-4 \%$ & 50 & $\begin{array}{c}\text { WIBOR (Warsaw } \\
\text { Interbank Offered }\end{array}$ & 500 PLN \\
& $1.75 \%)$ & & Rate) 1M or 3M \\
plus margin, about \\
Corporation
\end{tabular}

\section{Conclusions}

The conducted analysis of banks' loan offers, and interviews with bank managers led to the formulation of the conclusion that the simplified forms of accounting may influence the cost of credit, however, the most important reason for the problem is insufficient collaterals. Despite this, for many entrepreneurs, it may be a factor limiting the value of investments and may discourage them from applying for funding.

Business entities that prepare simplified financial statements should not encounter problems with access to external financing. Although keeping full accounting facilitates the running of a business's activity and allows for a decrease in the cost of capital in the case of applying for external financing, it is not necessarily the solution to all SME barriers for access to external sources of funding. 
Interviews results indicate that the problem of SMEs access to finance does not result from the form of accounting. It concerns more the knowledge of managers and their ability to plan investments in the business. The results of the interviews should, however, be compared with survey among small business owners to find out if the bank managers' statements stay in line with entrepreneurs' opinion. Therefore, future research should investigate how business owners choose their investments and plan investments cash flows, the pros and cons of simplified accounting according to business owners, what information business owners require to manage their enterprise, or the extent to which small business owners using simplified accounting keep additional financial information out of the accounting system.

\section{References}

Ayadi, R. \& Gadi, S. (2013) "Access by SMEs to Finance in the Southern and Eastern Mediterannean: What role for credit guarantee schemes?", MEDPRO Technical Report No. 35/2013, available online at: http://www.medproforesight.eu/ar/system/files/MEDPRO\%20TR\%20No\%2035\%20WP6\%20A yadi_0.pdf

Banasik, M. \& Napora-Lędźwa, H. (2014) “Ocena dostępności źródeł finansowania sektora mikro, małych i średnich, przedsiębiorstw na przykładzie województwa śląskiego [An Evaluation of the Availability of Funding to the MSME Sector as Exemplified by the Śląskie Province of Poland]", Zeszyty Naukowe Wyższej Szkoły Bankowej w Poznaniu, vol. 55(4): 51-79

Bauer, K. (2013) „Rachunkowość a potrzeby informacyjne małego przedsiębiorstwa [Accounting and the information needs of small businesses]", Finanse, Rynki Finansowe, Ubezpieczenia. Zeszyty Naukowe Uniwersytetu Szczecińskiego, vol. 58: 11-20

Beck, T., Demirgüç-Kunt, A. \& Soledad Martínez Pería, M. (2008) "Bank Financing for SMEs around the World Drivers, Obstacles, Business Models, and Lending Practices Policy. Research Working Paper; No. 4785", World Bank, available online at: https://openknowledge. worldbank.org/handle/10986/6315

Berger, A.N. \& Udell, G.F. (1995) "Relationship lending and lines of credit in small firm finance", The Journal of Business, vol. 68(3): 351-381

Berger, A. N. \& Frame, W.S. (2007) "Small business credit scoring and credit availability", Journal of Small Business Management, vol. 45(1): 5-22

Bergner, S.M. \& Heckemeyer, J.H. (2016) "Simplified Tax Accounting and the Choice of Legal Form", European Accounting Review, December 2016: $1-21$

Biernat-Jarka, A. \& Planutis, E. (2013) "Credit Guarantee Scheme for the SME Sector in Poland against the Background of the Selected EU Member States", 
Economic Science for Rural Development Conference Proceedings, vol. 30: 32-37

Brzeska, A. (2013) „Podatkowa księga przychodów i rozchodów jako przydatne źródło informacji dla mikroprzedsiębiorstw" [Tax Receipts and Disbursements as a Useful Source of Information for Micro-Enterprieses], Studia Ekonomiczne Regionu Łódzkiego, vol. X: 95-107

Buk, H. (2012) „Dyskusyjność wartości informacyjnej zestawienia zmian w kapitale własnym" [The usefulness of the statement of changes in equity], Zeszyty Teoretyczne Rachunkowości [Theoretical Journal of Accounting], vol. 66 (122):17-28

Cassar, G. (2004) "The financing of business start-ups", Journal of Business Venturing, vol. 19(2): 261-283

Czaja-Cieszyńska, H. (2009) „Użyteczność informacyjna uproszczonych form ewidencyjnych małych i średnich przedsiębiorstw na tle rozwiązań podatkowych w Polsce" [nformation Usefulness of Forms of Records for Small and Medium Sized Enterprises Against the Background of the Polish Tax System], Zeszyty Naukowe Uniwersytetu Szczecińskiego, vol 549: 172181

Czajkowska, A. (2013) „Rola poręczeń i funduszy poręczeniowych w finansowym wsparciu przedsiębiorców indywidualnych" [The Role of Sureties and Guarantee Funds in the Financial Support of Individual Entrepreneurs], Przedsiębiorczość i zarzadzanie, Tom XIV (6)

Dalberg Global Development Advisors (2011) Report on Support to SMEs in Developing

Countries Through Financial Intermediaries, available online at: http://www.eib.org/attachments/dalberg_sme-briefing-paper.pdf

Duan, H., Han, X. \& Yang, H. (2009) "An analysis of causes for SMEs financing difficulty”, International Journal of Business and Management, vol. 4 (6): 7475

European Parliament (2012) Motion for a European Parliament Resolution on Improving access to finance for SMEs, 2012/2134(INI), available online at: http://www.europarl.europa.eu/sides/getDoc.do?pubRef=//EP//TEXT+REPORT+A7-2013-0001+0+DOC+XML+V0//EN

Fedak, Z. \& Osikowicz, M. (2009) „Optymalny model rachunkowości małych firm [Optimum model of accounting of small and medium enterprises]", [in]: Kamela-Sowińska A. (red.), Zasoby i procesy $w$ rachunkowości jednostek gospodarczych, Warsaw: Difin

Fundacja Rozwoju Biznesu (2013) Raport Ustugi Księgowe w Polsce. Edycja 2013[Report Bookkeeping Services in Poland. Edition 2013], Warsaw

Porter, G.A. \& Norton, C.L. (2014) Financial Accounting: The Impact on Decision Makers, United States: Cengage Learning, Inc

Jaworski, J. (2009) „Podatkowa księga przychodów i rozchodów jako źródło prognozowania i oceny kondycji finansowej mikroprzedsiębiorstwa" [Tax book of receipts and expenditure as a basis for forecasting and evaluation of 
financial position in a microenterprise], Zeszyty Teoretyczne Rachunkowości, vol. 48(104): 43-60

Joźwicka, A. \& Zakrzewska-Bielawska, A. (2014) „Kompetencje Pracowników a Outsourcing Służb Finansowo-Księgowych w Małych Przedsiębiorstwach” [Competence of employees and outsourcing of financial \& accounting service in small companies], Zeszyty Naukowe Politechniki Łódzkiej, vol. 57 (1188): $27-40$

Kaczmarczyk, A. (2014) „Polityka rachunkowości w małych i średnich przedsiębiorstwach" [Accounting Policy and Small and Medium-Size Enterprise], Studia Ekonomiczne / Uniwersytet Ekonomiczny w Katowicach, Nr 201:142-150

Klimczak K. \& Krasodomska J. (2017) "The Role and Current Status of IFRS in the Completion of National Accounting Rules - Evidence from Poland", Accounting in Europe, vol. 14 (1-2): 158-163

Kulczycki, M. (2016) „Polityka banków w zakresie wsparcia finansowego konkurencyjności małych i średnich przedsiębiorstw" [Banks' Policy as Regards Financial Support for Competitiveness of Small and Medium-Sized Enterprises], Zeszyty Naukowe Uczelni Vistula, vol. 51 (6): 47-72

Martyniuk, T. \& Martyniuk, O. (2016) „Uproszczenia w Sprawozdawczości MikroI Małych Przedsiębiorstw. Mit Czy Rzeczywistość?" [Simplifications in Financial Reporting of Micro- And Small Enterprises. Myth or Reality?]", Studia Ekonomiczne. Zeszyty Naukowe Uniwersytetu Ekonomicznego w Katowicach, vol. 268: 144-154

Maszczak, T. (2015) „Zakres informacyjny uproszczonego sprawozdania finansowego jednostki małej" [The information scope of the condensed financial statement of small undertakings], Nauki o Finansach, vol. 3 (24): $127-150$

Mikócziová, J. (2010) "Sources of Investment Finance in Firms in Slovakia", Journal of Competitiveness, vol. 1/2010: 67-73

Mścibrodzka, K. (2014) „Wyniki finansowe mikro-, małych i średnich przedsiębiorstw prowadzących księgi przychodów i rozchodów w latach 2012 i 2013 na tle lat poprzednich" [Financial Performance of Micro Firms and Small and Medium-Sized Enterprises Keeping Revenue and Expense Ledgers in 2012 and 2013 against the Background of Previous Years], Zeszyty Naukowe Uczelni Vistula, vol. 35/2014: 232-255

Nassr, I.K. \& Wehinger, G. (2015) "Opportunities and limitations of public equity markets for SMEs", OECD Journal: Financial Market Trends, vol. 2015 (1): 49-84

Nowak, E. (2015) "The usefulness of information disclosed in company annual activity reports", Research Papers of the Wroclaw University of Economics [Prace Naukowe Uniwersytetu Ekonomicznego we Wroclawiu], issue 375: $117-125$

Palazuelos, C.E., Herrero, C.A. \& del Corte, J.M. (2017) “Are credit risk analysts concerned about the audit of the financial statements of SMEs?" Universia Business Review, 1st Quarter, issue 53:150-187 
Pogodzińska-Mizdrak, E. (2008) "Przegląd ekonomicznych i pozaekonomicznych problemów małych i średnich przedsiębiorstw w Polsce" [A Review of Economic and Non - Economic Problems of Polish Small and Medium Sized Enterprises]", Finanse, rynki finansowe, ubezpieczenia. Zeszyty Naukowe Uniwersytetu Szczecińskiego, vol. 11: 235-249

Schiffer, M. \& Weder, B. (2001) "Firm Size and the Business Environment: Worldwide Survey Results", International Finance Corporation, Discussion Paper, no. 43, Washington, DC: World Bank and the International Finance Corporation, available online at:

https://openknowledge.worldbank.org/handle/10986/13988

Starczewska-Krzysztoszek, M. (2014) Curriculum Vitae mikro, małych i średnich przedsiębiorstw 2014. Finansowanie działalności i rozwoju [Cirriculum Vitae of micro, small and medium enterprises 2014. Financing of development and activity], Warsaw: Konfederacja Lewiatan

Sobolewski, D. (2013) „Wpływ autooceny mikro-, małych i średnich przedsiębiorstw na badanie wiarygodności kredytowej przez fundusze pożyczkowe" [The Influence of Self-Evaluation on Micro, Small and Medium-sized Enterprises in Examining Creditworthiness through Loan Funds], Zeszyty Naukowe Wyższej Szkoły Bankowej w Poznaniu, vol. 47(2): 121-139

Szczypa, P. (2015) „Ewidencja kosztów w mikroprzedsiębiorstwach i jej wartość informacyjna. Stan obecny i postulowane kierunki zmian" [Records of Costs in Micro-Enterprises and Its Information Value: Current Status and Postulated Trends], Konińskie Studia Społeczno-Ekonomiczne, vol 1(2):185-197

Takats, G. (2013) „Koncepcja sprawozdawczości finansowej mikropodmiotów przyczynek do dyskusji" [Financial Reporting Concept of Micro Entities Discussion Paper], Prace Naukowe Uniwersytetu Ekonomicznego we Wrocławiu, vol. 313: 137-148

Udell, G. F. (2015) "SME Access to Intermediated Credit: What Do We Know, and What Don't We Know?", Reserve Bank of Australia, Conference Volume: 61109

Żabiński, A. (2011) „Możliwości wykorzystania karty podatkowej jako narzędzia rozwoju mikroprzedsiębiorczości w gminach" [The Possibilities of Using the Tax Card as a Tool for Development of Micro Enterprises in the Municipalities], Prace Naukowe Uniwersytetu Ekonomicznego we Wroctawiu, vol. 167: 600-609

Volkov, A. \& Laing, G. K. (2012) "Assessing the Value of Graphical Presentations in Financial Reports", Australasian Accounting Business \& Finance Journal, vol. 6(3): 85-107

The Act on accounting of 29 September 1994, Journal of Laws, number 121, position 591 (Dz.U. 1994 n. 121)

The Act on tax on registered income of 20 November 1988, number 144, position 930 (Dz.U. z 1998 r. n. 144) 
Does simplified accounting limit small and micro companies' access to bank financing?

The Act on tax for individuals of July 1991, number 80, position 350 (Dz.U. $1991 \mathrm{n}$. 80)

\section{Appendix 1 Interviews information}

\begin{tabular}{lll}
\hline No. & Interviewee & Date \\
\hline 1 & Director of the regional division of the bank & 07.12 .2015 \\
2 & Bank consultant & 08.12 .2015 \\
3 & Bank consultant & 08.12 .2015 \\
4 & Bank consultant & 09.12 .2015 \\
5 & Bank consultant & 09.12 .2015 \\
\hline
\end{tabular}

i The research of consequences of introducing planned changes in the Accounting Act.

ii Requirements presented on the websites of Polish banks.

iii Because SMEs are not very willing to participate in surveys, the research among SMEs must be conducted by specialized agencies on a wide scale to obtain a minimum rate of response.

${ }^{\text {iv }}$ Notes were taken during the interviews 